\title{
The Impact of Auditor's Gender on Audit Fees: Case of Jordanian Auditors
}

\author{
Suzan Abed ${ }^{1} \&$ Jomana Al-badainah ${ }^{2}$ \\ ${ }^{1}$ Department of Accounting, Applied Science Private University, Amman, Jordan \\ 2 Department of Accounting, The WISE University, Amman, Jordan \\ Correspondence: Suzan Abed, Department of Accounting, Applied Science University, Amman, Jordan. Tel: \\ 962-6560-9999-1295. E-mail: s_abed@asu.edu.jo or susanabed_2002@hotmail.com
}

Received: April 7, 2013 Accepted: May 13, 2013 Online Published: June 18, 2013

doi:10.5539/ijbm.v8n14p127 URL: http://dx.doi.org/10.5539/ijbm.v8n14p127

\begin{abstract}
The objective of this study is to examine the relation between audit fees and gender.5 semi-structured interviews were conducted with Jordanian licensed female auditors. On the other hand, other 5 semi-structured interviews were conducted with male auditors to increase scrutiny of previous results. Qualitative analysis was used to analyse the data.The result documents that there is no relation between audit fees and audit gender. Furthermore, findings of the interviews report other factors affecting audit fees, namely; audit quality and audit competence. On the other hand, findings of interviews with male auditors reveal that female auditors are more likely to reject unethical behaviours. This research is limited to the fact that audit fees depends on audit quality; and audit quality is dependent on the competence and independence of the external auditors. The findings may not accurately generalize to auditors' reactions to client gender in practice due to few numbers of interviews. This study focuses on the possible gender-based differences in auditing which may have an impact on the fees paid by the audit clients.
\end{abstract}

Keywords: audit fees, auditors' gender, auditor ethics, interviews

\section{Introduction}

Accounting researchers have investigated various aspects of gender differences in the accountingprofession (Gold et al., 2009; Almer et al. 1998; Collins 1993). The potential consequences of gender differences have been subject to an increasing interest in the literature. For example, female directors have to demonstrate superior competence to reach top positions (Eagly \& Carli, 2003), and so they prepare themselves for the tasks more thoroughly (Fondas \& Sassalos, 2000; Huse \& Solberg, 2006). However, Management researches provide evidence that individuals frequently stereotype male managers as possessing high managerial abilities, while expecting that female managers lack the necessary attributes for managerial success (Heilman et al. 1989; Schein 2001).

Numerous studies have investigated the impact of gender bias in product and performance (Wenneras and Wold, 1997; Basow et al., 2006; Gold et al., 2009). The majority of these studies indicated the existence of gender bias is context dependent with a pro-male bias. Accounting and auditing are still strongly preferable by men in our society (Carnegie and Napier, 2010). Although male and female auditors receive the same education and training, normatively, onemight expect that they would exhibit similar audit judgments. However, extant research shows thatwomen are generally believed to be more ethical (Mocan, 2008) more risk averse (Levin, et al., 1988; Jianakoplos\&Bernasek, 1998; Byrnes et al. 1999; Schubert, 2006). The possible gender-based differences in all of these areas could have an impact on the fees paid by the audit clients. In other words, it seems reasonable to assume that female auditors are, on average, are rated significantly higher for trustworthiness, integrity and honestly than male auditors. That is, information provided by female and male auditors is not viewed upon as being equally credible which causes audit fees to be associated with auditor gender. As a result, it can be assumed that an audit fee isassociated with auditor being male or female. As aconsequence, it is important to empirically investigate the relationship between auditorgender and audit fees to find any potential evidence.

The remainder of this paper is organized into six sections. Section 2 presents previous studies and develops the study hypothesis. Section 2 describes the regulations of audit profession in Jordan. Section 4 describes methodology employed in the current paper. Section 5 presents the results of the study. Section 6 summaries the 
main conclusion of the study and provides recommendation for the study.

\section{Literature Reviews and Research Question}

Auditors add credibility to financial reporting by expressing an opinion about the fairness of the financial statements. To assure that credible information is purchased, managers use auditor reputation as indicator of information quality (Chaney and Philipich, 2002). As a result, Deis and Giroux (1992) highlighted that most of the companies use brand name (Big 4) as a proxy for signaling audit quality differences among audit firm size group.Choi et al. (2005) mentioned that differences in the level of actual fees across clients are more likely to reflect the cost of effort perceived by auditor. Thus, a higher audit fees implies higher audit quality either through more audit effort or through greater expertise of the auditor (Francis, 2004).

Most of previous studies on determinants of audit fees have concentrated on two major categories; clients attributes which receives more attention in prior studies such as size, risk, complexity of business and profitability (Simunic, 1980; Stice, 1991; Hackenbrack and Knechel, 1997; Hay et al., 2006). Also, auditor attributes are considered important drivers of audit fees such as reputation, experience, competition, industry (Palmrose, 1986; Pearson and Trompeter, 1994; hay et al., 2006 and Gonthier and Schatt, 2007). Based on above, accounting researches have investigated various aspects of attributes in accounting profession, but all these studies have not examined the potential gender effects on audit fees. Recently, Hardies et al. (2009) examined the relationship between auditor gender and audit fees and they found that the female audit engagement partner audit fees are higher than male counterparts. In the same manner, Khan et al. (1996) found that female auditors are rated significantly higher than male auditors for their credibility and trustworthiness. Accordingly, Tsui (1996) pointed out that higher level of ethics is associated with more independent behavior, and it seems sensible to assume that female auditors are more independent than male auditor. Based on the above, the current study investigates on the relation between audit fees and gender on Jordanian context.

\section{Background of Auditing in Jordan}

Audit practice has been covered by Law of Audit Profession 1985 and the Company Law 1997. Article 4 of Audit Profession 1985 stipulates that in order to be licensed auditor; the auditor must be Jordanian with good honorable personality and should meet at least one of the following requirements:The auditor should have a $\mathrm{PhD}$ degree in accounting with a minimum one year of experience in auditing; or a master degree in accounting with a minimum of two years' experience in auditing; or a bachelor degree in accounting with a minimum of three years' experience in auditing; or any holder of professional certificate accredited by professional body such as AICPA.

The law specifies that auditors should ensure the fairness of the financial statements based on professional guidelines. Also, law of audit profession has introduced the establishment of audit firms and recommended the establishment of Jordan Association of Certified Public Accountants (JACPA).

On the other hand, the Company Law 1997 highlighted the main responsibilities of auditors. These responsibilities include: auditing companies based on International Standards on Auditing (ISA), ensuring the effectiveness of internal control system in safeguarding the assets of the company and providing an audit report to the shareholders of the company.

\section{Research Methodology}

This section discusses the research instrument used in the current study to collect the required data and the methods that have been employed to analyze the data.

\subsection{Research Instrument}

Data were collected through semi-structured interviews with female licensed auditors in Amman-Jordan. The contact information for the interviewed auditors conducted from the website of the Jordan Association of Certified Public Accountants (JACPA) for the year 2011. The total number of female licensed auditors consists of 7 auditors from the total of 353 certified professional auditors as listed by JACPA in 2011. The interviews were carried out in the auditors' office of 5 (Note 1) female auditors in the period between the $7^{\text {th }}$ of November and the $20^{\text {th }}$ of November 2012, where each interview lasted up around 45 minutes. Despite the interviews information such as auditors' names, offices and other informationwere assured that they are confidential data (Kamla, 2005), they refused to record their interviews. So the researchers documented the interviews through detailed notes.

For cross validation and increasing scrutiny over the results of the interviews which were conducted with female auditors. 5 semi-structured interviews were conducted with male auditors selected randomly from auditors listed at the website of the Jordan Association of Certified Public Accountants (JACPA) for the year 2011. The 
interviews were carried out in Amman-Jordan in the period between the $4^{\text {th }}$ of January and the $18^{\text {th }}$ of January 2013. The interviews lasted up around 30 minutes.

Before conducted semi-structured interviews, interview guide was developed to help the interviewers to cover in the course of the interview instead of asking a formal schedule of questions to be asked in a set of order. The interview guide included five main themes were asked to female auditors:

- What are the problems you face when you start your business?

- What is the reaction of clients when they are deal with female auditors?

- Are you prefer hiring female auditor?

- What is the type of your clients?

- Do you charge higher fees regarding auditand non-audit fees than men?

And also the 2 main themes were asked to male auditors:

-What is the relation between audit fees and gender?

-Who violate the rules more male or female?

Interviews were carried out in a friendly and open atmosphere making sure that conducted interviews performed in conversational way and unbiased manner by asking the questions in a non-directional, leading, or loaded pattern. Interviews started by explaining the importance of the research and exploring the current situation of auditing profession in Jordan. Moreover, interviewees were offered to read the details information and the contact addresses of the researchers were offered for future research queries.

Subsequently, the same research questions were asked to the interviewee in different subsequences and phrasings. Detailed notes were written down of unique and common elements in the interview allowing the researchers to reconsider the research questions addressed in the interview guide.

\subsection{Analyzing the Data}

Before analyzing data, transcribing the data is very important which involve complete written forms of each interview. At the first Arabic transcripts were prepared afterwards they were translated into English. The translation from Arabic to English has been double checked to ensure accuracy. The analysis started by giving each transcript a clear identifiable code. Then, transcripts were analyzed by highlighting substantive statements. An analysis grid was then developed for each theme discussed during interviews, and used to assign each statement to a category. The process of selecting quotations was decided carefully by selecting the most representative with an eye of an honest balance (Gillham, 2000).

Licensed female auditors were targeted in interviews to examine the relation between audit fees and audit gender. The first impression that the researcher gained was the difficulty in conducting the interview. When contacting the audit office, employees refused to make any appointment and advised sending the company email explaining: purpose of the interview, type of questions that will be asked, and reason of choosing the audit office to be part in the interviews. However, a response has been received from the general manager's office after two weeks of sending two follow-up emails and dialing two phone calls and interviews with the general manager was approved. Furthermore, all of the female auditor interviewee have male partner whether husband, brother or father. The main job for the partner is to meet customers and provide advices regarding dealing with clients but audit service is performed by female auditors. However, in each time the interviewers asked question the interviewee looked at their partner in order to take green light from them before answer any question and they were very conservative and brief in their answers.

\section{Interviews Findings}

This section presents the findings of interviews with female and male auditors which were carried out to investigate on the relation between audit fees and gender.

\subsection{Interviews with Female Auditors}

The main objective of this study is to determine the relation between audit fees and auditor's gender. It is interesting to know how clients whether male or female feel toward female auditors; this is not the attention of the study. Such a detailed scrutiny clearly cannot be carried out by using numbers, percentages and statistics (Basit, 2003). However, carrying out interviews in a country such as Jordon provides new insights regarding this issue to add to the extant literature of various aspects of gender differences in the accounting profession. 


\subsubsection{Problems}

All of the interviewees had faced financial problems when they started their works in the audit offices. But they gained support from their family members.

\subsubsection{Relationship with Clients}

All of the interviewees agreed that there is no problem in dealing with clients regardless to their gender whether male or female. Likewise, some clients prefer dealing with male auditors than females. This justifies the existence of male partner in audit offices to help in dealing with clients. That is, the role of male partnerarises in order not to lose auditor' clients due to differences in cultural practices and religion backgrounds. This interprets why females were not talking openly in the interviews, especially because of limited number of female auditors in Amman which makes the probability of covering their names is so easy. This consistent with Tannen (1990) who highlighted that gender difference may explain why male state they wish female "would make their mind". The femine pattern is to use speech to elicit other's opinions before deciding because women do not value intrinsic ranking of preferences (Oakes and Hammond, 1995).However, clients' gender preferences, the audit and non-audit services are performed by female auditors.

\subsubsection{Recruitments of Female Auditors}

Interestingly, and although that interviews were conducted with female auditors, recruitment of female auditors is not preferable by female auditors. This accused by various personal responsibilities of females such as; maternity leave, childcare, housekeeping... etc. which eliminate her availability and increase her need for early leave and vacation time. So, male tend to attend longer hours at work whilst females achieve more works in total.

Also, ethical issues are considering in recruitment. Where females are indeed believed to be more ethical than men and female auditors are more likely to reject unethical behavior than male auditors. This result is consistent with social role theory as mentioned by Eagly (1987) and Mocan (2008).

\subsubsection{Type of Clients}

Most of clients perform audit services by female auditors were related to limited corporation, partnership and small family business. One of the interviewees performed audit services for limited numbers of corporations. This result is consistent with previous studies (e.g., Hardies et al., 2010; Marlow and Carter, 2004) who found that on average female auditors had significant small clients. Furthermore, all the interviewees agreed that they perform audit services in very high quality and they do follow up for their works in very high standards. This result is consistent with feminist theory that the admission of female into male-dominated fields will not change those fields.

\subsubsection{Audit Fees Regarding Audit and Non-Audit Services}

All of the interviewees were very conservative regarding audit fees, but they agreed that they charge only the audit fees which were determined by Jordan Association of Certified Public Accountants. This may be partially interpreted that all of female auditors tried to skip this question. However, the JACPA determines only the minimum fees of audit services and leaves the right for auditor to determine the suitable fees depends on the size of audit services.This result is similar to the result achieved by Deis and Giroux (1992) who highlighted that companies use brand name (Big 4) as a proxy for signaling audit quality and audit fees differences among audit firm size group; but this result is inconsistent with Khan et al (1996) and Hardies et al. (2009).

Moreover, interviewees were asked about fees charged for non-audit services, some of them replied that they charge fees similar to male auditors, but in general they have very limited number of non-audit services. This result is similar to the result achieved by Hardies et al. (2010). On the other hand, one of the interviewees mentioned that the fees of non-audit fees depend on the type, on the size of the service and on the type of the client. This can be interpreted by the fact that all female auditors were very conservative during conducting the interviews and also they might scare from providing information which could be useful for competitors in the market, even the fact that they were assured that their names and other information disclosed would be kept confidential.

\subsection{Interviews with Male Auditors}

Five male auditors were approached to understand the relation between audit fees and gender.

\subsubsection{Audit Fees and Gender}

All male auditors agreed that there is no relation between audit fees and auditors' gender. They referred to other 
factors that affect audit fees such as experience of auditors, service quality and accuracy that represented by time saving. This result is consistent with previous studies (e.g., Francis, 2004).

\subsubsection{Unethical Behavior}

Most of the interviewees approved that female auditors are more likely to reject unacceptable violation of the Code of Professional Conduct; this result is consistent with previous studies such as (Mocan, 2008). In contrast, male auditors granted that they are more competence to discover unethical behavior.

\section{Conclusion}

The objective of this study was to investigate any expected relation between auditors' gender and audit fees.Findings of interviews of female and male auditors revealed that there are no differences between audit fees and gender.Moreover, the results documented that female in general are more likely to refuse any unethical behavior or any violation of the ethics of professional codes.

Future research could be conducted to examine any potential relation between audit fees and other factors such as; corporate governance, internal auditing and auditor specialization. Further research is also needed to help female auditors in understanding the persistent effects of implicit gender stereotypes, since auditing is still strongly gender-typed in favor of men in our society.

The results of this study should be considered in the context of its inherent limitations. For example, cultural differences can be observed between different countries through the way in which business is conducted and what might be acceptable and what is not. Cultural differences are also evidenced through professional judgments. The secretiveness of some cultures may make it difficult for some audit firms to form or join international networks or to experience other cultures and share information and experience. More research is necessary to investigate the obstacles faces female auditors during conducting their jobs. Additionally, the research sample is relatively small, limited to few number of licensed female and male auditors which affects the generalizability of the findings of the study.

\section{References}

Almer, E. D., Hopper, J. R., \& Kaplan, S. E. (1998). The Effect of Diversity-related Attributes on Hiring, Advancement and Voluntary Turnover Judgments. Accounting Horizons, 12(1), 1-17.

Basit, T. N. (2003). Manual or Electronic? The Role of Coding in Qualitative Data Analysis. Educational Research, 45(2), 143-154. http://dx.doi.org/10.1080/0013188032000133548

Basow, S. A., Phelan, J. E., \& Capotosto, L. (2006). Gender Patterns in College Students' Choices of their Best and Worst Professors. Psychology of Women Quarterly, 30(1), 25-35. http://dx.doi.org/10.1111/j.1471-6402.2006.00259.x

Byrnes, J. P., Miller, D. C., \& Schafer, W. D. (1999). Gender Differences in Risk Taking: A Meta-Analysis. Psychological Bulletin, 125, 367-383. http://dx.doi.org/10.1037/0033-2909.125.3.367

Chaney, P. K., \& Philipich, K. L. (2002). Shredded Reputation: The Cost of Audit Failure. Journal of Accounting Research, 40(4), 1221-1245. http://dx.doi.org/10.1111/1475-679X.00087

Choi, J. H., Kim, J. B., Liu, X., \& Simunic, D. A. (2005). Audit Pricing, Legal Liability Regimes, and Big 4 Premium: Theory and Cross-Country Evidence. Working Paper, University Of British Columbia.

Collins, K. M. (1993). Stress and Departures from the Public Accounting Profession: A Study of Gender Differences. Accounting Horizons, 7(1), 29-38.

Carnegie, G. D., \& Napier, C. J. (2010). Traditional Accountants and Business Professionals: Portraying the Accounting Profession after Enron. Accounting, Organizations and Society, 35(1), 360-376. http://dx.doi.org/10.1016/j.aos.2009.09.002

Deis, D. R. Jr., \& Giroux, G. A. (1992). Determinants of Audit Quality in the Public Sector. The Accounting Review, 67(3), 462-479.

Eagly, A. H. (1987). Six Differences in Social Behavior: A Social-Role Interpretation. Hillsdale (NJ): Lawrence Erlbaum Associates.

Eagly, A., \& Carli, L. (2003). The Female Leadership Advantage: An Evaluation of the Evidence. The Leadership Quarterly, 14, 807-834. http://dx.doi.org/10.1016/j.leaqua.2003.09.004

Fondas, N., \& Sassalos, S. (2000). A Different Voice in the Boardroom: how the Presence of Women Directors Affects Board influence over Management. Global Focus, 12, 13-22. 
Francis, J. R. (2004). What do we know about Audit Quality? British Accounting Review, 36(4), 345-368. http://dx.doi.org/10.1016/j.bar.2004.09.003

Gillham, B. (2000). The Research Interview. Continuum: London.

Gold, A., Hunton, J. E., \& Gomaa, M. I. (2009). The Impact of Client and Auditor Gender on Auditors' Judgments. Accounting Horizons, 23(1), 1-18. http://dx.doi.org/10.2308/acch.2009.23.1.1

Gonthier, B., \& Schatt, A. (2007). Determinants of Audit Fees for French Quoted Firms. Managerial Auditing Journal, 22(2), 139-160. http://dx.doi.org/10.1108/02686900710718654

Hackenbrack, K., \& Knechel, R. (1997). Resource Allocation Decisions in Audit Engagements. Contemporary Accounting Research, 14(3), 481-99. http://dx.doi.org/10.1111/j.1911-3846.1997.tb00537.x

Hardies, K., Breesch, D., \& Branson, J. (2009). Perceived Audit Quality: The Relationship between Auditor Gender and audit Fees. University of Brussels, Belgium.

Hardies, K., Breesch, D., \& Branson, J. (2010). Female Auditors in Belgium: Striking Figures and Facts. Accountancy and Bedrijfskunde, 30(4), 15-28.

Hay, D., Knechel, W. R., \& Wong, N. (2006). Audit Fees: A Meta-Analysis of the Effect of Supply and Demand $\begin{array}{llll}\text { Attributes. } & \text { Contemporary }\end{array}$ http://dx.doi.org/10.1506/4XR4-KT5V-E8CN-91GX

Heilman, M. E., Block, C., Martell, R., \& Simon, M. (1989). Has Anything Changed? Current Characterizations of Males, Females and Managers. The Journal of Applied Psychology, 74, 935-942. http://dx.doi.org/10.1037/0021-9010.74.6.935

Huse, M., \& Solberg, A. (2006). Gender-related Boardroom Dynamics: How Scandinavian Women Make and Can Make Contributions on Corporate Boards. Women in Management Review, 21, 113-130. http://dx.doi.org/10.1108/09649420610650693

Jianakoplos, N., \& Bernasek, A. (1998). Are Women more Risk Averse? Economic Inquiry, 36, 620-630. http://dx.doi.org/10.1111/j.1465-7295.1998.tb01740.x

Kamla, R. (2005). Social Accounting in a Selection of Arab Countries: Critical and Postcolonial Perspectives. Unpublished Doctoral Thesis, Herriot-Watt University.

Khan, Z. U., Chawla, S. K., \& Devine, E. A. (1996). Impact of Gender, Race, and Dress on Choice of CPA's. Journal of Applied Business Research, 13(1), 53-68.

Levin, I., Snyder, M., \& Chapman, D. (1988). The Interaction of Experimental and Situational Factors and Gender in A Simulated Risky Decision-Making Task. Journal of Psychology, 122, 173-181. http://dx.doi.org/10.1080/00223980.1988.9712703

Marlow, S., \& Carter, S. (2004). Accounting for Change: Professional Status, Gender Disadvantage and $\begin{array}{llll}\text { Self-Employment. Women in } \quad \text { Management } & \text { Review, }\end{array}$ http://dx.doi.org/10.1108/09649420410518395

Mocan, N. (2008). What Determines Corruption? International Evidence from Microdata. Economic Inquiry, 46(4), 493-510. http://dx.doi.org/10.1111/j.1465-7295.2007.00107.x

Oakes, L. S., \& Hammond, T. A. (1995). Biting the Epistemological Hand-Feminist Perspectives on Science and their Implications for Accounting research. Critical Perspective on Accounting, 6, 49-75. http://dx.doi.org/10.1006/cpac.1995.1007

Palmrose, Z. (1986). Audit Fees and Auditor Size: Further Evidence. Journal of Accounting Research, 24(1), 97-110. http://dx.doi.org/10.2307/2490806

Pearson, T., \& Trompeter, G. (1994). Competition in the Market for Audit Services: the Effect of Supplier Concentration on Audit Fees. Contemporary Accounting Research, 11(1), 115-135. http://dx.doi.org/10.1111/j.1911-3846.1994.tb00439.x

Tannen, D. (1990). You Just Don't Understand. New York: Random House.

Schein, V. E. (2001). A Global Look at Psychological Barriers to Women's Progress in Management. The Journal of Social Issues, 57(4), 675-688. http://dx.doi.org/10.1111/0022-4537.00235

Schubert, R. (2006). Analyzing and Managing Risks - on the Importance of Gender Difference in Risk Attitudes. Managerial Finance, 32, 706-715. http://dx.doi.org/10.1108/03074350610681925 
Simunic, D. A. (1980). The Pricing of Audit Services: Theory and Evidence. Journal of Accounting Research, Spring, 161-190. http://dx.doi.org/10.2307/2490397

Stice, J. (1991). Using Financial and Market Information to Identify Pre-engagement Factors Associated with Lawsuits against Auditors. The Accounting Review, 66(3), 516-533.

Tsui, J. S. L. (1996). Auditors' Ethical Reasoning: Some Audit Conflict and Cross Cultural Evidence. The International Journal of Accounting, 31(1), 121-133. http://dx.doi.org/10.1016/S0020-7063(96)90016-3

Wennerås, C., \& Wold, A. (1997). Nepotism and Sexism in Peer-review. Nature, 387(6631), 341-344. http://dx.doi.org/10.1038/387341a0

\section{Note}

Note 1.2 female auditors cancelled their scheduled interviews due to lack of their interest and time.

\section{Copyrights}

Copyright for this article is retained by the author(s), with first publication rights granted to the journal.

This is an open-access article distributed under the terms and conditions of the Creative Commons Attribution license (http://creativecommons.org/licenses/by/3.0/). 